\title{
ABDOMINAL ANGIOSTRONGYLIASIS WITH INVOLVEMENT OF LIVER HISTOPATHOLOGICALLY CONFIRMED: A CASE REPORT
}

\author{
José Luis QUIRÓS(1,2), Ernesto JIMÉNEZ(1), Raúl BONILLA(1), Isabel ARCE(2), Cristian HERNÁNDEZ(1) \& Yendry JIMÉNEZ(2)
}

\begin{abstract}
SUMMARY
Human abdominal angiostrongyliasis is a zoonotic disease caused by ingestion of the L3 larvae of Angiostrongylus costaricensis. The human infection gives rise to a pathological condition characterized by acute abdominal pain, secondary to an inflammatory granulomatous reaction, marked eosinophilia and eosinophilic vasculitis. Most commonly this disease is limited to intestinal location, primary ileocecal, affecting the mesenteric arterial branches and intestinal walls. We present one of the few cases reported around the world with simultaneous involvement of the intestines and liver, including proved presence of nematodes inside the hepatic arteriole.
\end{abstract}

KEYWORDS: Angiostrongylus costaricensis; Eosinophilic gastroenteritis; Abdominal angiostrongylosis; Hepatic lesions; Eosinophilic hepatitis.

\section{INTRODUCTION}

The clinical features of abdominal angiostrongyliasis have been reported in Costa Rican children since $1952^{5,10}$. Nevertheless, a characterization of the clinical syndrome was not presented until 1967, by MORERA \& CÉSPEDES ${ }^{2,13}$. Successively, in the year 1971 they identified the new species Angiostrongylus costaricensis as the etiologic agent of the previously described human disease ${ }^{12}$. This nematode is found throughout the Americas, from the United States to Argentina ${ }^{9,10}$. In Costa Rica up to 500 cases are reported annually ${ }^{11}$.

Human abdominal angiostrongyliasis is a zoonotic disease ${ }^{2,12} . A$. costaricensis mature adults usually live in mesenteric arteries of wild rodents, more commonly in Sigmodon hispidus and Rattus rattus ${ }^{14,17}$. The nematode also requires terrestrial mollusks as intermediate hosts, especially from the family Veronicellidae ${ }^{4,8}$. Children may accidentally eat slugs, or fruits and vegetables contaminated through mucoid secretions $\mathbf{s}^{1,19,21}$.

Patients suffering from this illness commonly have clinical signs similar to those of acute appendicitis. Sometimes intestinal obstruction, perforation and/or hemorrhage are found $d^{2,5,6,7}$. A percentage of patients are ill for months, presenting relapsing episodes of abdominal pain ${ }^{6}$. Often, patients exhibit leukocytosis and eosinophilia ${ }^{6,7}$.

Abdominal angiostrongyliasis confirmed diagnosis is made during microscopic examination of surgical specimens ${ }^{6}$. Lesions are most frequently found in the ileocecal region ${ }^{6,7}$; however, localization in lymph nodes, omentum, liver, and testicles has also been observed ${ }^{1,7,15,22}$.

\section{CASE REPORT}

A 13-year-old male patient from Puriscal-Costa Rica was admitted to the Emergency service of the San Juan de Dios Hospital on January $8,2006$.

The patient had no pathological history and complained of 15 days of abdominal pain, predominantly in the right iliac fossa; abdominal cramps, diarrhea, stools without blood, vomits of ingested content and fever.

Physical examination showed: temperature $38.8^{\circ} \mathrm{C}$, pulse $110 \mathrm{bpm}$. respiratory rate 22 breaths a minute and $150 / 90 \mathrm{mmHg}$ blood pressure. The patient was dehydrated and pale; he presented tachycardia, decreased peristaltic rhythm, muscular resistance throughout the right lower quadrant and painful palpation of right iliac fossa. McBurney, Rovsing, Dumphy and rebound signs were positive.

Laboratory tests revealed the following results: hemoglobin $12.4 \mathrm{~g} / \mathrm{dL}$; hematocrit $37 \%$; white cell count $23100 / \mathrm{mm}^{3}$ with $41 \%$ neutrophils ( $6 \%$ bands cells), $10 \%$ lymphocytes, $10 \%$ monocytes and $39 \%$ eosinophils. Glucose $109 \mathrm{mg} / \mathrm{dL}$, ureic nitrogen $5 \mathrm{mg} / \mathrm{dL}$, creatinine $0.7 \mathrm{mg} / \mathrm{dL}$, sodium $132 \mathrm{mmol} / \mathrm{L}$, potassium $4.5 \mathrm{mmol} / \mathrm{L}$, chloride $104 \mathrm{mmol} / \mathrm{L}$, AST $56 \mathrm{IU} / \mathrm{L}$, ALT 76 IU/L, alkaline phosphatase 160 IU/L, GGT $44 \mathrm{IU} / \mathrm{L}$, total bilirubin $0.6 \mathrm{mg} / \mathrm{dL}$, total proteins $6.6 \mathrm{~g} / \mathrm{dL}$,

(1) Department of Pathology, San Juan de Dios Hospital, Costa Rica.

(2) Department of Anatomy, Universidad de Costa Rica.

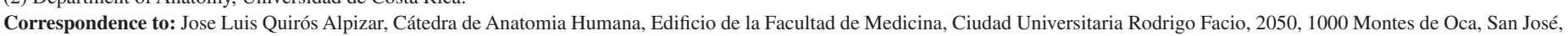
Costa Rica. Tel.: (506)25114488. E-mail: dr.quiros@ gmail.com 


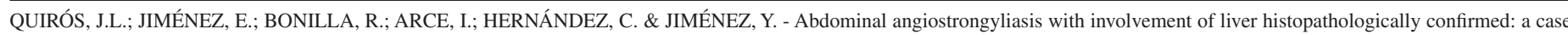
report. Rev. Inst. Med. Trop. Sao Paulo, 53(4): 219-22, 2011.

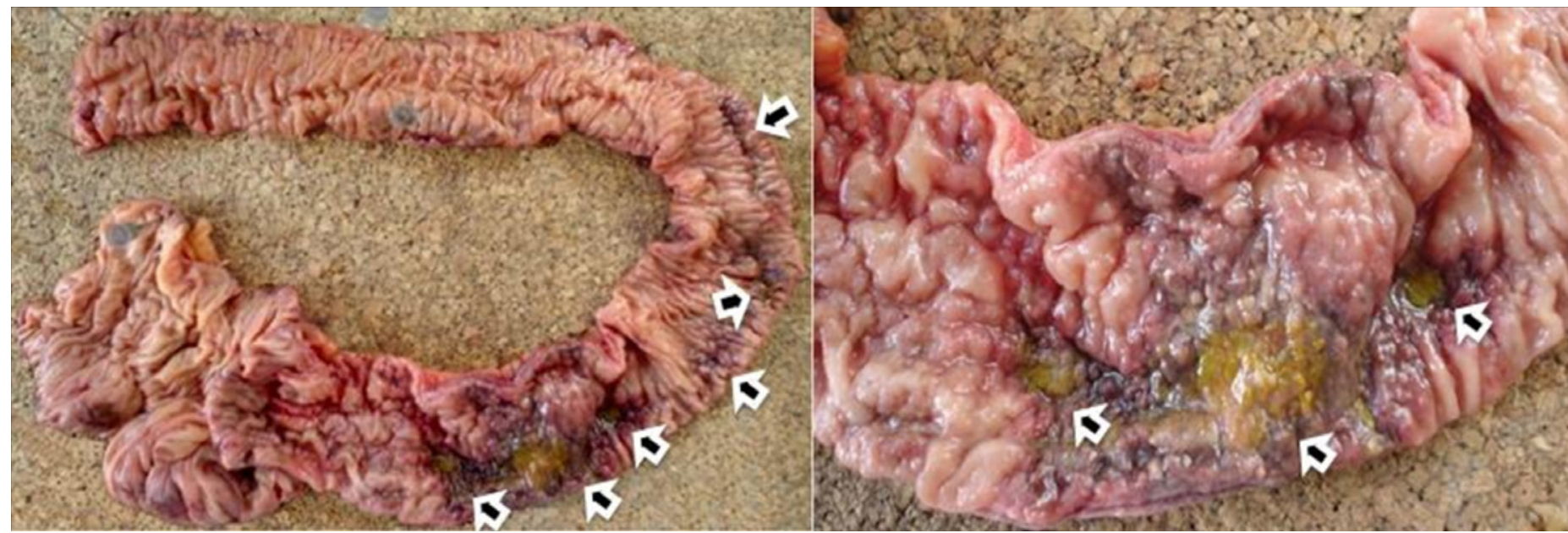

Fig. 1 - Left panel: Macroscopic view of hardened yellow-colored areas (arrows) in large intestine mucosa. Right panel: detail.

albumin $2.8 \mathrm{~g} / \mathrm{dL}$. Urinalysis: density 1,020, pH 5.0 leukocytes 3/450D, erythrocytes $0 / 450 \mathrm{D}$, no cylinders, no nitrites, few epithelial cells.

An exploratory laparotomy was performed, with the following findings: abundant peritoneal fluid and necrotic patches without perforation $30 \mathrm{~cm}$ distal from the ileocecal valve. Hardened yellowcolored areas of approximately $1 \mathrm{~cm}$ to $2 \mathrm{~cm}$ of length were found in large intestine (Fig. 1 and 2), ileocecal region and liver. Two enlarged lymph nodes were located in the ascending mesocolon and retroperitoneum.

Resection of distal ileum and right hemicolectomy were performed, followed by an end-to-end ileo-transverse anastomosis. Liver biopsy was performed in suspicious zones of lesion. Samples of intestine and liver were fixed for histopathological examination.

After surgery, the following serological tests were performed: Typhoid $\mathrm{H}$, paratyphoid, paratyphoid B, brucella, proteus OX 19, all of which were negative.

Anti-A.costaricensis antibodies were detected by a latex agglutination

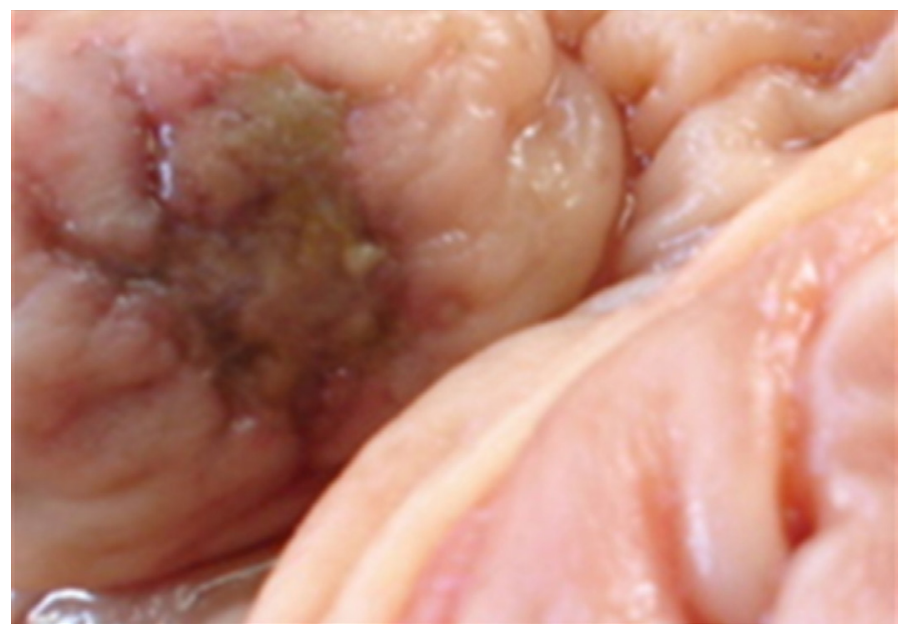

Fig. 2 - Macroscopic view of necrotic ulcer in colonic mucosa. test performed at the Parasitology Laboratory of San Juan de Dios Hospital.

During the first four postsurgical days the patient presented fever peaks that normalized thereafter. He initiated oral tolerance during the fifth postsurgical day and was discharged from the hospital two days later. The patient was maintained under medical control with satisfactory evolution.

\section{MICROSCOPIC FINDINGS}

Cecal appendix showed mild serositis, due to eosinophilic inflammatory infiltration. The small intestine was partially affected by ulcerated zones which showed inflammatory eosinophilic infiltration and extended from the submucosa to the subserosa. Some submucous arterioles, containing adult nematode structures in their lumen, presented wall fibrinoid necrosis and fibrin thrombi, and were surrounded by areas of necrosis and hemorrhage.

Transversally sectioned nematode(s) displayed a longitudinal muscle layer under the hypodermis, interrupted by lateral cords, which were longitudinal inward expansions of hypodermis to the pseudocoelom. The adult worm(s) appeared to be female, with internal structures corresponding to the uterus and intestine. Eggs were not detected in any of the sections. Based upon the location, the morphologic features and the epidemiology, it was identified as A. costaricensis. Some nematode sections presented degenerated aspect.

Regional lymphatic nodes showed multifocal areas of hemorrhagic necrosis. The liver showed zones of periportal inflammatory eosinophilic infiltration associated with necrotic areas. Hepatic arterioles presented fibrinoid necrosis (Fig. 3 and 4). Inside the vessel lumen fibrin-like trombus were found, as well as nematode structures.

\section{DISCUSSION}

The intestinal histopathologic findings described in the present case are similar to those reported in the literature for the disease; namely eosinophilic infiltration of the intestinal wall, granulomatous reaction, 


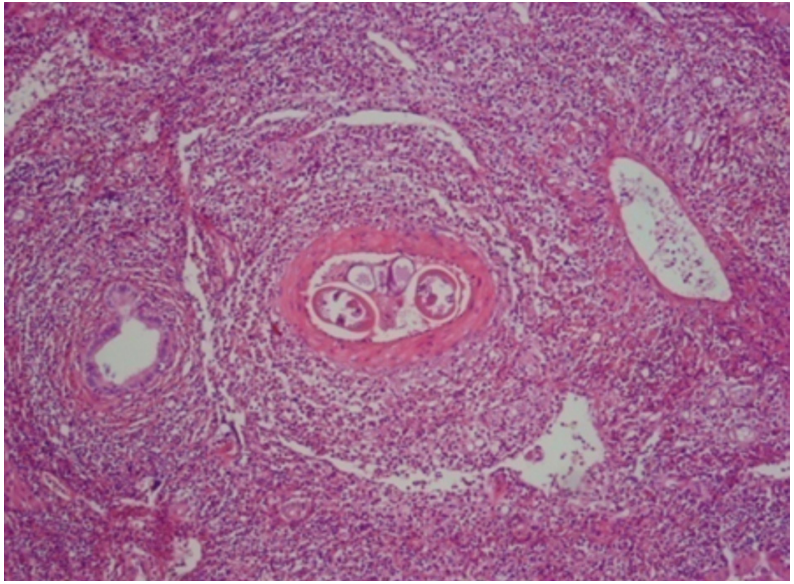

Fig. 3 - Transversal sections of adult nematode(s) are seen inside arterioles with eosinophilic inflammatory infiltrate in the surrounding tissues (HE; 200x)

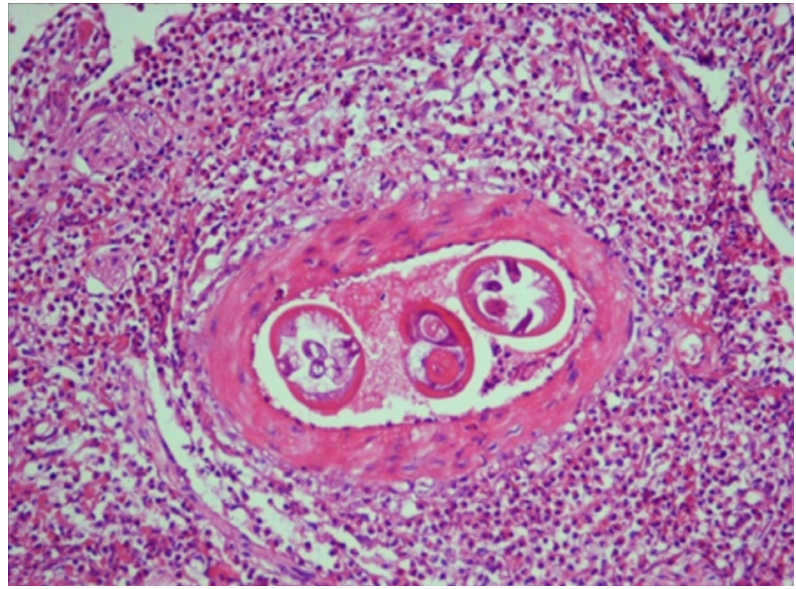

Fig. 4 - Hepatic arteriole presenting fibrinoid necrosis and intra-luminal nematode(s) structures (HE; 400x).

and eosinophilic vasculitis, affecting arteries, veins, lymphatic vessels and capillaries $^{2,3,5}$. Intestinal involvement is the most common presentation in both rodents and human beings, primarily affecting the ileocecal region ${ }^{1}$. Therefore, what is remarkable of this particular report is the simultaneous finding of worms in the liver, especially with a demonstrated histological presence of the parasite inside a hepatic arteriole.

We raised the issue of how the parasite reaches this extraintestinal location. Historically, in 1980 LORÍA \& LOBO published the findings of hepatic lesions in seven of 90 cases of abdominal angiostrongyliasis, four of these cases presented eosinophilic infiltration on histological specimens ${ }^{7}$. Later on, in 1982 MORERA et al. recorded for the first time histological evidence of the presence of A. costarricensis in the portal vein of two patients; the medical team considered the disease as a visceral larva-migrans-like syndrome ${ }^{22}$.

The fact that there are few cases with extraintestinal findings reported in humans could suggest that special conditions are required for the migration of the parasite. Thus, the extraintestinal clinical presentation may be the result of an ectopic migration ${ }^{1}$.
In 2005 MOTA \& LENZI presented a redescription of the migratory pathways of A. costaricensis, based on experimental Sigmodon hispidus infection ${ }^{16}$. The study design included 216 rodents at three months of age, divided into groups of eight animals orally infected with 100, 500 and 4000 L3 larvae. Nematodes were found in lungs, mesenteric lymph nodes, pancreas, liver, spleen, kidneys and even in the brain. In the specific case of the liver, two main migration pathways were proposed: (1) lymphatic/venous-arterial and (2) venous portal.

It is also important to consider that some of these locations have not been commonly reported in either human beings or rodents. Additionally, previous investigation has fully demonstrated that the intensity of infection is a major factor, since the production of infective stages, and in many cases pathology, is dependent on the number of parasites ${ }^{20}$. This was considered by MOTA et al. as an explanation for some findings.

Other important elements to consider in the parasite-host relationship are the genetic characteristics inherent to each one and the fact that human beings are accidental hosts. Host genetic factors strongly affect the outcome of the infectious disease. Experimental infection of different mouse strains with this nematode has shown great variability in mortality. The search of specific host susceptibility loci is an active field of research worldwide. In humans details of the mechanisms of host resistance and/or susceptibility are largely unknown because of the complexity of interactions ${ }^{18}$.

We hope the present report will serve to encourage further research and discussion about this tropical disease.

\section{RESUMEN}

\section{Angiostrongiliasis abdominal con lesión hepática histopatológicamente confirmada}

La enfermedad conocida como angiostrongiliasis abdominal humana es una zoonosis causada por la ingestión del estadio larval L3 de Angiostrongylus costaricensis. En el ser humano, esta infección provoca un estado patológico caracterizado por dolor abdominal agudo, secundario a una reacción inflamatoria granulomatosa; eosinofilia marcada y vasculitis eosinofílica. Comúnmente el cuadro se encuentra limitado a una localización intestinal, predominantemente ileocecal, que compromete las ramas de la arteria mesentérica y la pared intestinal. Presentamos uno de los pocos casos reportados alrededor del mundo con hallazgos simultáneos en intestino e hígado; se incluye la demostración histológica del nemátodo dentro de la arteriola hepática.

\section{ACKNOWLEDGMENTS}

We would like to thank Pedro Morera and Elizabeth Abrahams for their help with this manuscript.

\section{REFERENCES}

1. Abrahams E. Angiostrongyliasis abdominal: notas sobre el diagnostico. Rev Biomed. 2007; $18: 37-45$.

2. Céspedes R, Salas J, Mecbel S, Tropel L, Mullner F, Morera P. Granulomas entéricos y linfáticos con intensa eosinofilia tisular producidos por un estrongilideo (Strongylata): patología. Act Méd Costarric. 1967;10:235-55. 
QUIRÓS, J.L.; JIMÉNEZ, E.; BONILLA, R.; ARCE, I.; HERNÁNDEZ, C. \& JIMÉNEZ, Y. - Abdominal angiostrongyliasis with involvement of liver histopathologically confirmed: a case report. Rev. Inst. Med. Trop. Sao Paulo, 53(4): 219-22, 2011.

3. Graeff-Texeira C, Camillo-Coura L, Lenzi HL. Histopathological criteria for the diagnosis of Angiostrongyliasis. Parasit Res. 1991;77:606-11.

4. Graeff-Teixeira C, Thomé JW, Pinto SC, Camillo-Coura L, Lenzi HL. Phyllocaulis variegatus - an intermediate host of Angiostrongylus costaricensis in south Brazil. Mem Inst Oswaldo Cruz. 1989;84:65-8.

5. Hulbert TV, Larsen RA, Chandrasoma PT. Abdominal Angiostrongyliasis mimicking acute appendicitis and Meckel's diverticulum: report of a case in the United States and review. Clin Infect Dis. 1992;14:836-40.

6. Kramer MH, Greer GJ, Quiñónez JF, Padilla N, Hernández B, Arana B, et al. First reported outbreak of abdominal angiostrongyliasis. Clin Infect Dis. 1998;26:365-72.

7. Loría-Cortés R, Lobo-Sanahuja JF. Clinical abdominal angiostrongyliasis. A study of 116 children with intestinal eosinophilic granuloma caused by Angiostrongylus costaricensis. Am J Trop Med Hyg. 1980;29:538-44.

8. Mendonca CL, Carvalho OS, Mota EM, Lenzi HL. Development of Angiostrongylus costaricensis Morera and Céspedes 1971 (Nematoda: Angiostrongylidae) larvae in the intermediate host Sarasinula marginata (Semper 1885) (Mollusca: Soleolifera). Parasitol Res. 2008;102:861-5.

9. Morera P. Abdominal angiostrongyliasis: a problem of public health. Parasitol Today. $1985 ; 1: 173-5$.

10. Morera P. Abdominal angiostrongyliasis. In: Strickland G, editor. Hunter's Tropical Medicine. $7^{\text {th }}$ ed. Philadelphia: WB Saunders; 1991. p. 771-3.

11. Morera P, Amador J. Prevalencia de la angiostrongiliosis abdominal y la distribución estacional en la precipitación. Rev Costarric Salud Pública. 1998;7:1-14.

12. Morera P, Céspedes R. Angiostrongylus costaricensis n.sp. (Nematodo: Metastrongyloidea), a new lungworm occurring in man in Costa Rica. Rev Biol Trop. 1971;18:173-85.

13. Morera P. Granulomas entéricos y linfáticos con intensa eosinofilia tisular producidos por un estrongilideo (Strongylata, Railliet y Henry, 1913). II Aspecto parasitológico (nota previa). Acta Med. Costarric. 1967;10:257-65.
14. Morera P. Investigación del huésped definitivo de Angiostrongylus costaricensis (Morera y Céspedes, 1971). Bol Chil Parasitol. 1971;25:133-4.

15. Morera P, Perez F, Mora F, Castro L. Visceral larva migrans-like syndrome caused by Angiostrongylus costaricensis. Am J Trop Med Hyg. 1982;31:67-70.

16. Mota EM, Lenzi HL. Angiostrongylus costaricensis: complete redescription of the migratory pathways based on experimental Sigmodon hispidus infection. Mem Inst Oswaldo Cruz, 2005;100:407-20.

17. Mota EM, Lenzi HL. Angiostrongylus costaricensis life cycle: a new proposal. Mem Inst Oswaldo Cruz. 1995;90:707-9.

18. Ohno T, Ishih A, Tanaka S, Nishimura M, Terada M. Chromosomal mapping of host susceptibility loci to Angiostrongylus costaricensis nematode infection in mice. Immunogenetics. 2002;53:925-9.

19. Pena GP, Andrade Filho J, Assis SC. Angiostrongylus costaricensis: first record of its occurrence in the State of Espirito Santo, Brazil, and a review of its geographic distribution. Rev Inst Med trop Sao Paulo. 1995;37:369-74.

20. Quinnell RJ. Genetics of susceptibility to human helminth infection. Int J Parasitol. 2003;33:1219-31.

21. Rodriguez R, Dequi RM, Peruzzo L, Mesquita PM, Garcia E, Fornari F. Abdominal angiostrongyliasis: report of two cases with different clinical presentations. Rev Inst Med trop Sao Paulo. 2008;50:339-41.

22. Ruiz PJ, Morera P. Spermatic artery obstruction caused by Angiostrongylus costaricensis Morera and Cespedes 1971. Am J Trop Med Hyg. 1983;32:1458-9.

Received: 21 November 2009

Accepted: 20 May 2011 